\title{
Selective Effects of Cyclophosphamide Therapy on Activation, Proliferation, and Differentiation of Human B Cells
}

\author{
Li-Ping Zhu, Thomas R. Cupps, Gall Whalen, and Anthony S. Fauci \\ Laboratory of Immunoregulation, National Institute of Allergy and Infectious Diseases, \\ National Institutes of Health, Bethesda, Maryland 20892
}

\begin{abstract}
The immune function of $B$ lymphocytes from 12 patients with nonneoplastic immune-mediated diseases receiving chronic lowdose $(2 \mathrm{mg} / \mathrm{kg}$ per d) cyclophosphamide (CY) was evaluated. There was a selective and differential suppressive effect of $\mathrm{CY}$ therapy on the various stages of the $B$ cell cycle including activation, proliferation, and differentiation. The proliferative responses to Staphylococcus aureus Cowan strain I (SAC) and mitogenic concentrations of anti- $\mu$ were suppressed. In contrast, $B$ cells that have been presumably activated in vivo proliferated with a normal pattern when exposed to $B$ cell growth factor in vitro. Chronic low-dose CY therapy also suppressed B cell differentiation. Secretion of immunoglobulin by $B$ cells following in vitro triggering with $S A C$ and a $T$ cell supernatant was suppressed in CY-treated patients. Moreover, differentiation of the large in vivo-activated $B$ cells (which do not require an in vitro activation signal) in the presence of appropriate $T$ lymphocyte supernatant was also suppressed. This selective suppression of $B$ cell function at multiple points in the $B$ cell cycle may be responsible for the efficacy of $\mathrm{CY}$ therapy in certain antibody and immune complex-mediated diseases.
\end{abstract}

\section{Introduction}

Cyclophosphamide (CY) ${ }^{1}$ administered chronically in low doses has been used with increasing frequency and success in the treatment of nonneoplastic diseases characterized by hyperreactivity of the immune system (1-3). This therapeutic approach has been particularly effective in the treatment of a number of systemic vasculitic syndromes including Wegener's granulomatosis (4), systemic necrotizing vasculitis (5), and lymphomatoid granu-

Address correspondence to Dr. Thomas R. Cupps, Department of Medicine, Division of Rheumatology, Immunology and Allergy, Georgetown University Medical Center, 3800 Reservoir Road, N.W., Washington, DC 20007.

Dr. Zhu's current address is Dong Dan San Tiso 5, Peking, China.

Received for publication 6 May 1986 and in revised form 3 December 1986.

1. Abbreviations used in this paper: AET-SRBC, 2-aminoethylisothiouronium bromide-treated sheep red blood cells; BCDF, B cell differentiation factor; BCGF, B cell growth factor; CNS, central nervous system; Con A, concanavalin A; CY, cyclophosphamide; FMF, flow microfluorometric; ISC, immunoglobulin-secreting cell; MLR-SN, mixed lymphocyte reaction supernatant; PFC, plaque-forming cell; PHA, phytohemagglutinin; PWM, pokeweed mitogen; PWM-SN, pokeweed mitogen supernatant; SAC, Staphylococcus aureus Cowan strain I; sIg, surface immunoglobulin; TCD, T cell depleted; UF, unfractionated.

The Journal of Clinical Investigation, Inc.

Volume 79, April 1987, 1082-1090 lomatosis (6). Although a variety of immunomodulatory effects have been demonstrated in animal models after short-term highdose CY treatment protocols (7-11), information on the effects of chronically administered low-dose CY on the immune system in man is limited (12-16). Recently, we have demonstrated a clear-cut selective effect of CY therapy on mitogen-stimulated Ig production (16). In the present report, we evaluate the effect of chronic low-dose CY therapy on the distinctive phases of the B cell cycle.

Investigation in this and other laboratories has resulted in delineation of the sequential events in the human B cell activation cascade (17-21). Using this model system, it has been demonstrated that resting $B$ cells can be activated by a number of initial signals. Following activation, the B cells are then capable of responding to a number of $T$ cell-derived growth factors such as B cell growth factor (BCGF) or differentiation factors such as $B$ cell differentiation factor (BCDF). In the present study, we demonstrate the selective effects of in vivo-administered $\mathrm{CY}$ therapy on distinct phases of these activation, proliferation, and differentiation processes.

\section{Methods}

Subjects. 12 patients, 4 men and 8 women ranging in age from 14 to 57 $\mathrm{yr}$, were studied while being treated with oral $\mathrm{CY}$ as inpatients under the systemic vasculitis protocol at the National Institutes of Health. Clinical, laboratory, and therapeutic parameters of these patients are summarized in Table I. All patients were in sustained clinical remission as previously defined $(4,5)$ at the time the studies were performed. All patients had a urinary creatinine clearance of $>60 \mathrm{ml} / \mathrm{min}$ at the time of study. 5 of the 12 patients were also receiving alternate-day prednisone therapy. Blood from these individuals was drawn $48 \mathrm{~h}$ after the last dose of prednisone to avoid corticosteroid-related effects (T. R. Cupps and A. S. Fauci, unpublished observations, and ref. 16). Patients were initially treated with $\mathrm{CY}(2 \mathrm{mg} / \mathrm{kg}$ per d) orally as a single daily dose with subsequent adjustments of the CY dosage to avoid a peripheral leukocyte count below 3,000 cells $/ \mathrm{mm}^{3}$. In addition, seven patients were studied at varying times after successfully completing a therapeutic trial of $\mathrm{CY}$ therapy. The clinical, laboratory, and therapeutic parameters of these latter patients are summarized in Table II. Patients were studied between 1.5 and 132 mo after completion of the CY therapy. 13 normal individuals ranging in age from 25 to 44 yr were studied simultaneously with the patients as controls.

Cell separations. Heparinized venous blood was immediately diluted 1:1 (vol/vol) with iced phosphate-buffered saline (PBS), pH 7.4, and unfractionated (UF) mononuclear cell suspensions were obtained by Ficoll-Hypaque density centrifugation (Ficoll, Pharmacia Fine Chemicals, Inc., Piscataway, NJ; Hypaque, Winthrop Laboratories, New York, NY) (16). The UF mononuclear cells were initially depleted of $T$ cells by rosetting with 2-aminoethylisothiouronium bromide-treated sheep red blood cells (AET-SRBC) followed by separation by Ficoll-Hypaque density centrifugation (22). Further $T$ cell depletion was performed by incubating the AET-SRBC rosette-negative cells with Leu-1 (anti-pan T lymphocyte) mouse monoclonal antibody (Becton-Dickinson \& Co., Sunnyvale, CA) at $2 \mu \mathrm{g}$ per $10^{7}$ cells at $4^{\circ} \mathrm{C}$ for $45 \mathrm{~min}$. Following this, 
Table I. Clinical, Laboratory, and Therapeutic Parameters in the Patient Groups in Clinical Remission While Receiving CY

\begin{tabular}{|c|c|c|c|c|c|c|c|c|c|}
\hline Subject & Age & Sex & Diagnosis & $\begin{array}{l}\text { Organ system } \\
\text { involvement }\end{array}$ & $\begin{array}{l}\text { Total peripheral } \\
\text { white cell counts* }\end{array}$ & Lymphs* & Monos* & $\begin{array}{l}\text { Total duration } \\
\text { of CY } \mathbf{R x}^{*}\end{array}$ & $\begin{array}{l}\text { Dose of } \\
\text { CY Rx* }\end{array}$ \\
\hline & $y r$ & & & & cells $/ \mathrm{m}^{3}$ & $\%$ & $\%$ & mo & $m g / d$ \\
\hline 1 & 20 & $\mathbf{F}$ & Wegener's granulomatosis & Sinus, lung, renal & 4,100 & 5 & 4 & 22 & 75 \\
\hline 2 & 54 & $\mathbf{F}$ & $\begin{array}{l}\text { Isolated angiitis of the } \\
\text { central nervous system } \\
\text { (CNS) }\end{array}$ & CNS & 5,200 & 10 & 5 & 22 & 25 \\
\hline 3 & 54 & $\mathbf{M}$ & Wegener's granulomatosis & Sinus, lung, trachea & 5,500 & 10 & 11 & 14 & 150 \\
\hline 4 & 57 & $\mathbf{F}$ & $\begin{array}{l}\text { Isolated angiitis of the } \\
\text { CNS }\end{array}$ & CNS & 4,700 & 18 & 8 & 36 & 25 \\
\hline 5 & 45 & $\mathbf{M}$ & Wegener's granulomatosis & $\begin{array}{l}\text { Upper airways, } \\
\text { lung, kidney }\end{array}$ & 5,900 & 10 & 13 & 34 & 75 \\
\hline 6 & 22 & $\mathbf{F}$ & Wegener's granulomatosis & Skin, joint, lung & 4,800 & 18 & 10 & 18 & $50 / 75$ \\
\hline 7 & 34 & $\mathbf{F}$ & $\begin{array}{l}\text { Isolated angiitis of the } \\
\text { CNS }\end{array}$ & CNS & 4,000 & 15 & 14 & 15 & 50 \\
\hline 8 & 14 & $\mathbf{M}$ & Wegener's granulomatosis & $\begin{array}{l}\text { Upper airways, eye, } \\
\text { lung, kidney }\end{array}$ & 3,700 & 25 & 9 & 10 & 75 \\
\hline 9 & 45 & $\mathbf{F}$ & $\begin{array}{l}\text { Systematic necrotizing } \\
\text { vasculitis }\end{array}$ & $\begin{array}{l}\text { CNS, lung, nerve, } \\
\text { muscle }\end{array}$ & 4,900 & 11 & 6 & 7 & 50 \\
\hline 10 & 69 & $\mathbf{M}$ & Wegener's granulomatosis & $\begin{array}{l}\text { Trachea, sinus, eye, } \\
\text { lung, kidney }\end{array}$ & 4,200 & 19 & 8 & 39 & 75 \\
\hline 11 & 32 & $\mathbf{F}$ & Wegener's granulomatosis & $\begin{array}{l}\text { Ears, lung, kidney, } \\
\text { joints }\end{array}$ & 3,400 & 18 & 6 & 28 & 75 \\
\hline 12 & 32 & $\mathbf{F}$ & Wegener's granulomatosis & Lung & 7,400 & 15 & 10 & 6 & 100 \\
\hline
\end{tabular}

* Represents information at the time of the investigative studies.

$1 \mathrm{ml}$ of $25 \%$ rabbit serum per $10^{7}$ cells was added and the mixture was incubated in a $37^{\circ} \mathrm{C}$ waterbath for $1 \mathrm{~h}$. The cells were then washed in RPMI 1640 and evaluated for the presence of monocytes by nonspecific esterase staining (23). Cell preparations with $>40 \%$ esterase-positive cells were further depleted of monocytes by adherence to plastic tissue culture flasks in $0.2 \%$ heat-inactivated fetal calf serum (FCS) in RPMI 1640 in $5 \% \mathrm{CO}_{2}$ in air at $37^{\circ} \mathrm{C}$ for $15-30 \mathrm{~min}$. The percent of esterase-positive cells ranged between 30 and $40 \%$ of the T cell-depleted cells (TCD). The adequacy of the $T$ cell depletion was demonstrated by the failure to respond to the T cell mitogens concanavalin A (Con A; Sigma Chemical

Table II. Clinical, Laboratory, and Therapeutic Parameters in Patient Groups in Remission Off CY

\begin{tabular}{|c|c|c|c|c|c|c|c|c|c|}
\hline Subject & Age & Sex & Diagnosis & Involvement & $\begin{array}{l}\text { Total peripheral } \\
\text { white cell count }\end{array}$ & Lymphs* & Monos* & $\begin{array}{l}\text { Total duration } \\
\text { of CY Rx }\end{array}$ & $\begin{array}{l}\text { Time off } \\
\text { therapy* }\end{array}$ \\
\hline & & & & & cells $/ \mathrm{m}^{3}$ & $\%$ & $\%$ & mo & mo \\
\hline $1^{\ddagger}$ & 17 & $\mathbf{M}$ & Wegener's granulomatosis & Sinus, lung, renal & 4,900 & 20 & 7 & 36 & 1.5 \\
\hline $2^{8}$ & 34 & $\mathbf{M}$ & Wegener's granulomatosis & $\begin{array}{l}\text { Sinus, lung, } \\
\text { kidney, CNS }\end{array}$ & 5,800 & 16 & 1 & 96 & 10.0 \\
\hline $3^{\ddagger}$ & 47 & $\mathbf{M}$ & Wegener's granulomatosis & $\begin{array}{l}\text { Upper airway, } \\
\text { lung, kidney }\end{array}$ & 5,600 & 21 & 10 & 42 & 17.0 \\
\hline 4 & 63 & $\mathbf{M}$ & $\begin{array}{l}\text { Systematic necrotizing } \\
\text { vasculitis }\end{array}$ & Skin, visceral & 8,100 & 25 & 12 & 48 & 18.0 \\
\hline $5^{\S}$ & 36 & $\mathbf{M}$ & Wegener's granulomatosis & $\begin{array}{l}\text { Sinus, lung, } \\
\text { kidney, CNS }\end{array}$ & 7,700 & 14 & 8 & 96 & 34.0 \\
\hline 6 & 24 & $\mathbf{F}$ & $\begin{array}{l}\text { Systematic necrotizing } \\
\text { vasculitis }\end{array}$ & $\begin{array}{l}\text { Skin, lung, } \\
\text { peripheral } \\
\text { nerves }\end{array}$ & 10,000 & 29 & 6 & 18 & 54.0 \\
\hline 7 & 57 & $\mathbf{M}$ & Wegener's granulomatosis & $\begin{array}{l}\text { Upper respiratory } \\
\text { tract, lung, } \\
\text { kidney }\end{array}$ & 9,200 & 21 & 6 & 46 & 132.0 \\
\hline
\end{tabular}

* Represents information at the time of investigative study. ${ }^{\ddagger}$ Also studied while on CY therapy. ${ }^{8}$ The same individual studied at different times. 
Co., St. Louis, MO) phytohemmaglutinin (PHA; Burroughs Wellcome Laboratories, Research Triangle Park, NC), and pokeweed mitogen (PWM; Gibco Laboratories, Grand Island, NY).

In some experiments, the TCD fractions were further monocyte depleted as described previously (23), with slight modification. Briefly, UF mononuclear cells were suspended in $0.2 \%$ FCS in RPMI and incubated at $37^{\circ} \mathrm{C}$ for $30 \mathrm{~min}$ to allow adherence to $4-\mathrm{mm}$ glass beads (Kimble Div., Owens-Illinois Inc., Toledo, OH). AET-SRBC rosetting cells were then depleted as described above, and the remainder of cells were incubated over Sephadex G-10 columns with 1\% FCS in RPMI 1640 for $15 \mathrm{~min}$ at $37^{\circ} \mathrm{C}$. The number of surface immunoglobulin-positive cells $\left(\mathrm{sIg}^{+}\right)$ranged between 70 and $85 \%$. The nonadherent cells that eluted from the column were $<5 \%$ esterase positive and were used as monocytedepleted B cells.

In the studies examining surface markers of B cell activation and cell size changes, monocyte depletion was accomplished by L-leucine methyl ester depletion as previously described in detail (24). These B cell preparations contained $55-75 \% \mathrm{sIg}^{+}$cells and had $<1 \%$ esterasepositive cells.

Mitogens. Staphylococcus aureus Cowan strain I (SAC) was obtained from American Type Culture Collection, Rockville, MD, treated as previously described (25), and used at a final concentration of 1:50,000 (vol/ vol). In cultures measuring blastogenic responses, the PWM was used at a final concentration of $1: 100$, PHA at $10 \mu \mathrm{g} / \mathrm{ml}$, and Con A at $5 \mu \mathrm{g} /$ $\mathrm{ml}$. The $\mathrm{F}\left(\mathrm{ab}^{\prime}\right)_{2}$ goat antihuman $\mu$ chain-specific (N. L. Cappel Laboratories, Inc., West Chester, PA) was used at a final concentration of 20$200 \mu \mathrm{g}$ protein $/ \mathrm{ml}$.

Generation of mixed lymphocyte reaction supernatants (MLR-SN). The MLR-SN was made by allogeneic coculture of $10^{6}$ AET rosettepositive cells from one donor with $10^{6} \mathrm{AET}$ rosette-negative cells from a second donor in 10\% FCS in RPMI 1640 with $2 \mathrm{mM}$ glutamine at a final volume of $2 \mathrm{ml}$ in 15 -mm diameter plastic wells (Linbro Division, Flow Laboratories, Inc., New Haven, CT). The supernatants were harvested at $48 \mathrm{~h}$, aliquoted, and stored at $-20^{\circ} \mathrm{C}$ until use.

Generation of PWM-stimulated supernatant (PWM-SN). The PWM$\mathrm{SN}$ was prepared from AET rosette-positive cells $\left(2 \times 10^{6} / \mathrm{ml}\right)$ by culturing the cells in 10\% FCS in RPMI 1640 with $2 \mathrm{mM}$ glutamine in 15-mm diameter plastic wells in a final PWM concentration of 1:200 in a final volume of $2 \mathrm{ml}$ per well. The supernatants were harvested after $48 \mathrm{~h}$. Control supernatants were obtained in a similar fashion except that PWM was added after the supernatant was harvested. Both PWM-induced and control supernatants were aliquoted and stored at $-20^{\circ} \mathrm{C}$ until used.

$B C G F$. Monoclonal BCGF from a human T-T cell hybridoma was used as previously described by Butler et al. (20).

Determination of sIg ${ }^{+}$cells. B lymphocyte counts were determined in UF and B cell-enriched populations of cells by detection of $\mathrm{sIg}^{+}$cells as previously detailed (16).

Cytoplasmic Ig staining. Cytopreps were prepared by cytocentrifugation, dried in air, and fixed with 5\% acetic acid-95\% ethanol for 15 min at $-12^{\circ} \mathrm{C}$. The slides were thoroughly washed with PBS and then stained with fluorescein-conjugated rabbit $\mathrm{F}\left(\mathrm{ab}^{\prime}\right)_{2}$ fragment antihuman IgG, IgA, and IgM with a high fluorescein-to-protein ratio (N. L. Cappel Laboratories, Inc.). The stained smears were first washed in PBS and then in tap water, and the percent of cells with intracytoplasmic staining was determined.

Flow microfluorometric (FMF) analysis of cell surface phenotypes. For analysis of B cell surface Ig isotype, $1 \times 10^{6} \mathrm{~B}$ cells were pelleted. Then $5 \mu$ l of mouse monoclonal antihuman IgM, IgA, or IgG antibody (Bethesda Research Laboratories, Gaithersburg, MD) was applied for 30 min at $4^{\circ} \mathrm{C}$. The cells were then washed twice in Hanks' balanced salt solution without phenol red (Gibco Laboratories) supplemented with $0.1 \%$ bovine serum albumin and $0.01 \%$ sodium azide. Then, $10 \mu \mathrm{l}$ of a 1:50 dilution of fluorescein-conjugated IgG fraction goat anti-mouse Ig (IgA + IgG + IgM, heavy and light chain; N. L. Cappel Laboratories, Inc.) was added, and the mixture was incubated for an additional $\mathbf{3 0}$ min at $4^{\circ} \mathrm{C}$. The cells were washed twice and resuspended in $0.5 \mathrm{ml}$ of wash solution for counting. The cells were analyzed by using a fluores- cence-activated cell sorter (FACS II; Becton-Dickinson \& Co.). The data were analyzed using a PDP 11/34 computer (Digital Equipment Corporation, Landover, MD). The FMF analysis was performed by using logarithmic amplification of the gain.

Monocyte- and T cell-depleted B lymphocyte preparations were evaluated for presence of cell surface markers of activation. Two monoclonal antibodies $4 \mathrm{~F}_{2}(26,27)$ and $5 \mathrm{E}_{9}(28)$ that bind to the surface of activated but not resting lymphocytes were tested. The cells were processed as described above.

Measurement of cell size. Cellular volume was measured with a Channelyzer (Coulter Electronics, Inc., Hialeah, FL) before and after 36-h stimulation with SAC (1:50,000 vol/vol final concentration) or anti- $\mu$ (100 $\mu$ g protein $/ \mathrm{ml})$.

Blastogenesis. Cell proliferation was assayed by incorporation of tritiated thymidine on day 3 except as noted. $10^{5}$ cells were placed in $10 \%$ FCS, RPMI 1640 , with $10 \mu \mathrm{g} / \mathrm{ml}$ gentamicin to a final volume of $0.2 \mathrm{ml}$ in round-bottomed microtiter plates (Flow Laboratories, Inc.) and cultured at $37^{\circ} \mathrm{C}$ in $5 \% \mathrm{CO}_{2} . \sim 16-20 \mathrm{~h}$ before harvesting on a Titertek cell harvester (Flow Laboratories, Inc.), each well was pulsed with $1 \mu \mathrm{Ci}$ of tritiated thymidine (6.7 Ci/mM; New England Nuclear, Boston, MA). Incorporated radioactivity was counted in a liquid scintillation counter (Model LS-350, Beckman Instruments Inc., Fullerton, CA). Each point was done in triplicate.

Cell viability. Cell viability was determined at various times during the culture period by trypan blue exclusion.

Determination of Ig-secreting cells (ISC). The ability of B lymphocytes to secrete Ig was measured in an indirect plaque-forming cell (PFC) assay using target sheep erythrocytes coated with staphylococcal protein $A$ and a developing rabbit antihuman polyvalent (anti-IgG, +IgA, +IgM) antibody (N. L. Cappel Laboratories, Inc.) as previously described in detail (29). Two protocols to stimulate TCD cell fractions to develop into ISC were employed. In the first assay, $5 \times 10^{5}$ TCD cells were cultured in $12 \times 75-\mathrm{mm}$ plastic tubes in the presence of $10 \%$ FCS, RPMI 1640 with $2 \mathrm{mM}$ glutamine, gentamicin $0.1 \%$ with SAC $1: 50,000$ (vol/vol) final concentration as previously described (18). On the second day after the culture was set up, $0.5 \mathrm{ml}$ of the culture supernatant was removed and replaced with $0.5 \mathrm{ml}$ of MLR-SN. After $6 \mathrm{~d}$, a PFC assay was performed on the cultured cells to determine the number of ISC. In the second assay, $5 \times 10^{5}$ TCD cells were cultured in 10\% FCS, RPMI 1640 with $2 \mathrm{mM}$ glutamine, $0.1 \%$ gentamicin, and $0.5 \mathrm{ml}$ PWM-SN to a total volume of $1 \mathrm{ml}$ in a $10 \times 75-\mathrm{mm}$ plastic tube (30). These cultures were also harvested after $6 \mathrm{~d}$ to determine the number of ISC.

Statistical analysis. Statistical evaluations were performed by using Student's two-tailed $t$ test.

\section{Results}

$C Y$ therapy suppresses $S A C$ and anti- $\mu$-induced proliferation of $B$ cells. Patients receiving chronic low-dose CY therapy have a profound suppression of $B$ cell proliferative responses to the $T$ cell-independent B cell mitogens SAC and anti- $\mu$ (Table III) when compared with normal individuals $(P>0.001)$. A number of possibilities could account for the poor B cell mitogenic responses including $(a)$ decreased number or viability of cultured B cells, $(b)$ a shift in the dose or kinetic response curves, (c) suppression from an accessory cell such as a monocyte, or $(d)$ impaired function of the B cells. Although the patients are relatively leukopenic (peripheral leukocyte count, $4,711 \pm 317$ cells per $\mathrm{mm}^{3}$ ), the percentage of $\mathrm{slg}^{+}$cells in the UF mononuclear cell populations in the patient $(8.3 \pm 7.5 \%)$ and control $(9.5 \pm 5 \%)$ groups were similar. The percentage of $\mathrm{sIg}^{+}$cells in the TCD fractions for patient $(45.8 \pm 7.5 \%)$ and control $(45.8 \pm 8.2)$ groups were also similar. In addition, the patterns for the sIg isotypes, $\gamma, \mu, \delta$, were similar for the two groups. Moreover, the numbers 
Table III. Suppression of $B$ Cell Blastogenic Responses to $S A C$ and Anti- $\mu$

\begin{tabular}{|c|c|c|c|}
\hline & \multicolumn{3}{|c|}{ Proliferative responses in $\mathrm{cpm}^{*}$} \\
\hline & Background & SAC & Anti- $\mu$ \\
\hline $\begin{array}{l}\text { Normal B cells with } \\
34 \% \text { monocytes }{ }^{\ddagger}\end{array}$ & $529 \dot{\dot{x}} 1.25$ & $3,953 \dot{\dot{x}} 1.46$ & $1,845 \dot{\dot{x}} 1.49$ \\
\hline $\begin{array}{l}\text { Patient B cells with } \\
32 \% \text { monocytes }\end{array}$ & $345 \dot{\dot{x}} 1.31$ & $802 \dot{\dot{x}} 1.33$ & $535 \dot{\dot{x}} 1.28$ \\
\hline $\begin{array}{l}\text { Patient B cells with } \\
<5 \% \text { monocytes" }\end{array}$ & $139 \dot{\dot{x}} 1.25$ & $323 \dot{\bar{x}} 1.75$ & $125 \dot{\dot{\dot{x}}} 1.70$ \\
\hline
\end{tabular}

* $10^{5}$ viable cells from the B cell-enriched fractions were cultured in microtiter wells, and tritiated thymidine was measured on day 3 . Final concentration of SAC 1:50,000 (vol/vol). Final concentration anti- $\mu$ ( $\mathrm{F}[\mathrm{ab}]_{2}$ goat antihuman IgM, $\mu$-chain specific) $100 \mu \mathrm{g} / \mathrm{ml}$ total protein.

‡Geometric mean $(\dot{\overline{\dot{X}}} \mathrm{SEM}) \mathrm{cpm}$ from 12 normals.

${ }^{6}$ Geometric mean $(\dot{\bar{X}}$ SEM) cpm from 10 patients being treated with CY.

"Geometric mean ( $\dot{\overline{\dot{X}}}$ SEM) cpm from 4 patients being treated with CY.

of monocytes in the patient ( $32 \pm 4 \%)$ and control group ( $34 \pm 6 \%)$ were maintained at a similar level to avoid the nonspecific suppressive effect of high percentages of monocytes. Decreasing the number of monocytes to $<5 \%$ as determined by nonspecific esterase-positive cells did not reconstitute the suppressed response (Table III). The next series of experiments were performed to determine if the decreased blastogenic responses of patient $B$ cells were due to alterations in the time kinetics of the response or shifts in the dose response curve of the mitogens (SAC and anti- $\mu$ ) employed. It was clearly demonstrated that the suppressed B cell mitogenic responses were not due to changes in the time kinetics (Fig. 1) or the dose response curves (Fig. 2). Finally, viability of cultured cells was similar for the patient and control groups. Taken together, these observations suggest that there is a profound functional suppression of $B$ cell mitogenic responses to $\mathrm{SAC}$ and anti- $\mu$ in patients receiving chronic low doses of CY.

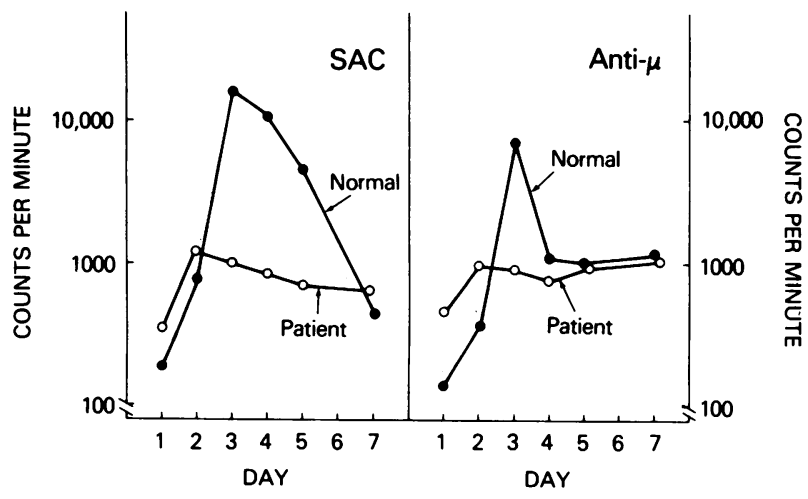

Figure 1. Geometric mean cpm of tritiated thymidine incorporation in B cell-enriched fraction from two patients treated with CY (open circle) and two normals (solid circles) following stimulation with SAC $1: 50,000$ and high-dose anti- $\mu(100 \mu \mathrm{g} / \mathrm{ml})$ (goat $\mathrm{F}\left[\mathrm{ab}^{\prime}\right]_{2}$ antihuman IgM, $\mu$-chain specific).
$C Y$ therapy alters $B$ cell size in peripheral blood. Following in vitro activation, normal human peripheral blood and tonsillar B cells enlarge (31). B cell enlargement occurs when cells enter the $G_{1}$ phase of the cell cycle before DNA synthesis. Peripheral blood B cells separated from patients receiving CY are significantly larger when compared with peripheral blood B cells from normals (Fig. $3 A$ ).

Following in vitro stimulation with anti- $\mu$ for $36 \mathrm{~h}$ in cultures, normal peripheral blood B cells enlarge, but B cells from CYtreated patients fail to enlarge further (Fig. $4 \mathrm{~B}$ ). To determine the significance of the in vivo enlargement of $B$ cells from $C Y$ treated patients, cell surface markers of activation, $4 \mathrm{~F}_{2}$ and $5 \mathrm{E}_{9}$ (31), were evaluated. We have previously demonstrated that following in vitro activation with SAC or anti- $\mu$, human B cells not only enlarge but also express the cell surface markers of activation, $4 \mathrm{~F}_{2}$ and $5 \mathrm{E}_{9}(31)$. Despite the in vivo enlargement, neither $4 \mathrm{~F}_{2}$ (normal $2.0 \pm 0.87$; CY-treated $1.7 \pm 0.67, n=4$ ) nor

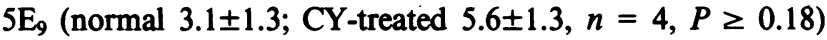
expression was significantly increased on the B cells from CYtreated patients.

Proliferative response to $B C G F$ is unaltered by $C Y$ therapy. We have previously demonstrated that a subset of normal peripheral blood B cells will proliferate in vitro when cultured with BCGF in the absence of any additional in vitro activation signals (21). Presumably, this BCGF-responsive subset of B cells from normal individuals has received some in vivo activation stimulus. If peripheral blood B cells are separated by size, the BCGFresponsive cells are enriched in the larger cell fractions. To evaluate for the presence of BCGF-responsive subsets, B cells from CY-treated patients were cultured with monoclonal BCGF in the absence of any additional in vitro activating signal (Fig. 4). The response to BCGF alone was similar in normals and patients. This observation suggests that patients being treated with CY have a subset of B cells in the peripheral blood similar to normals that has received some in vivo stimulus to activate them to a BCGF responsive state.

CY therapy suppresses $B$ cell differentiation. B cell differentiation following SAC stimulation as measured in a PFC assay was suppressed during treatment with CY (Fig. 5). This was seen in UF mononuclear cells. However, because it was unclear whether the suppression of differentiation was due to a defect at the B cell level or due to a lack of available $T$ cell-derived differentiation factors, the following experiments were performed. Normal or patient B cells were cultured in the presence or absence of exogenous $\mathrm{T}$ cell-derived differentiation factors provided by an MLR-SN, a standard source of BCDF (18). As can be seen (Fig. 5), neither normal nor patient $B$ cells alone responded to SAC with differentiation and Ig secretion. However, when MLR-SN was provided, normal B cells responded with differentiation whereas patient B cells still did not secrete Ig. Thus, the defect in differentiation in CY-treated patients cannot be explained by a lack of $\mathrm{T}$ cell-derived differentiation factor and is indeed at the level of the B cell itself.

To further evaluate the potential relationship between the defective B cell differentiation in CY-treated patients and the ability of these B cells to proliferate in response to growth factors, another assay system was employed. Because we had previously shown that patients have decreased proliferative responses to SAC (Table III), we stimulated patient and normal B cells (TCD suspensions) with a supernatant from PWM-stimulated normal T lymphocytes (PWM-SN). We had previously shown that when 


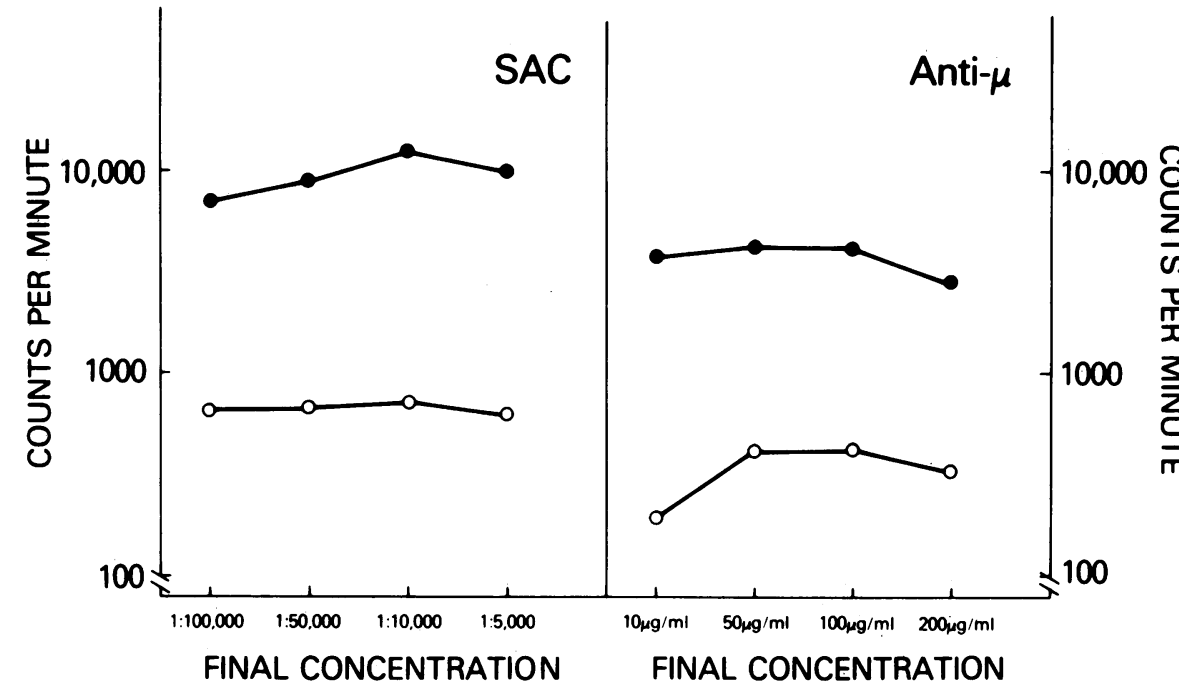

Figure 2. Geometric mean cpm of tritiated thymidine incorporation in two normals (solid circles) and two patients on CY (open circle) to varying doses of SAC and anti- $\mu$ (goat $\mathrm{F}\left[\mathrm{ab}^{\prime}\right]_{2}$ antihuman IgM, $\mu$-chain specific) harvested on day 3 . normal human peripheral blood B cells are separated into small (resting) B cells and large, presumably in vivo-activated B cells, the proliferative and PFC responses that develop in the presence of PWM-SN are found in the fraction of large activated B cells (T. R. Cupps and A. S. Fauci, unpublished observations). Of note is the fact that $\mathrm{B}$ cells from CY-treated patients respond normally to PWM-SN with regard to proliferation (Fig. $6 \mathrm{~A}$ ). However, despite the presence of activated B cells that can proliferate normally, the ability of these preactivated B cells to differentiate is markedly suppressed (Fig. $6 \mathrm{~B}$ ). The failure of the B cells from patients treated with CY to differentiate does not appear to be the result of a shift in the kinetic response curve (Fig. 7). Data from one study is shown. A similar pattern was seen in a second study (data not shown). A similar defect in differentiation was noted in CY-treated patients when intracy- toplasmic antibody was determined (normal B cells, background, 3.5 $\pm 0.5 ; \mathrm{SAC}+\mathrm{MLR}-\mathrm{SN}, 41.5 \pm 3.5 ; \mathrm{PWM}-\mathrm{SN}, 22.5 \pm 4.5$; B cells from CY-treated patients, background, 2.0 \pm 0.5 ; SAC + MLR-SN, 3.0 \pm ; PWM-SN, $3.5+1.5$ percent positive intracytoplasmic staining, $n=2$ for all points). These data indicate that B cells, which presumably have been activated in vivo, will proliferate in the presence of appropriate soluble factors but do not go on to differentiate as do B cells from normals.

Recovery of $B$ cell function following cessation of $C Y$ therapy. The results of B cell functional assays in seven patients studied between 1.5 and $132 \mathrm{mo}$, after successfully completing a course of CY therapy are summarized in Table IV. The rate at which the B cell function recovers following cessation of CY therapy may vary. The B cell function of the first patient in Table IV, studied 1.5 mo after completing therapy, is nearly completely

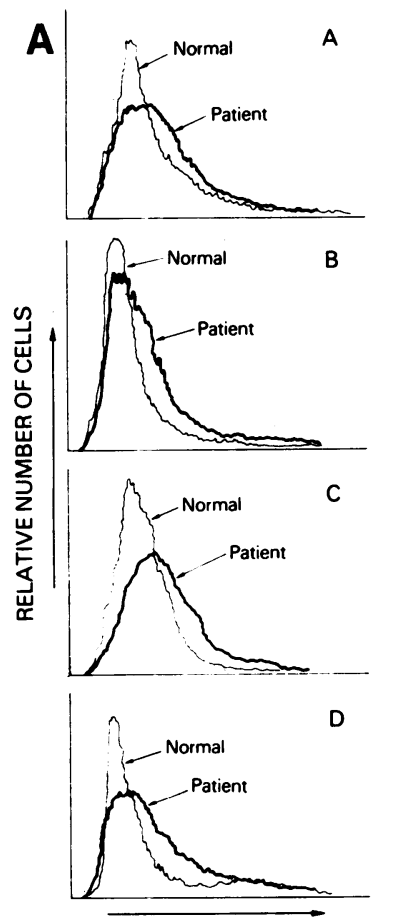

INCREASING CELL SIZE (Volume)
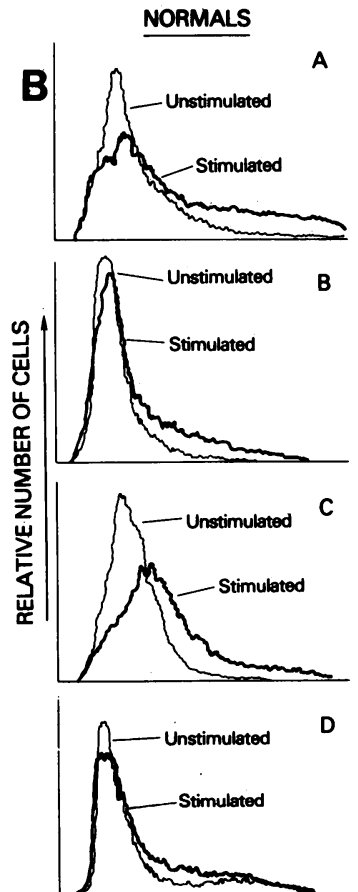

INCRÉASING CELL SIZE (Volume)
PATIENTS
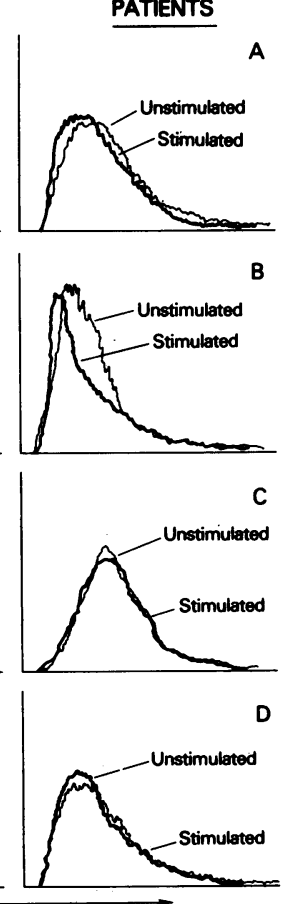
(L-leucine methyl ester technique) B cells from four patients on CY and from four normals. (B) Cell size changes in monocyte-depleted (L-leucine methyl ester technique) B cells in four patients on CY and four normals. Lighter lines represent unstimulated B cells, whereas heavier lines represent B cells stimulated with anti- $\mu$ (goat $F\left[\mathrm{ab}^{\prime}\right]_{2}$ antihuman IgM, $\mu$-chain specific) for $36 \mathrm{~h}$. 


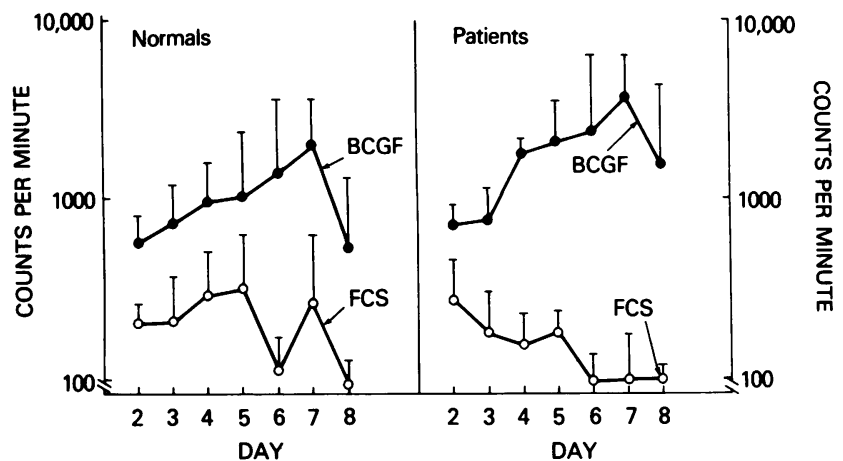

Figure 4. Geometric mean cpm ( $\dot{\overline{\times}} \mathrm{SEM})$ in B cells with FCS alone (open circles) or with monoclonal BCGF (solid circles) in six normals and six patients being treated with $\mathrm{CY}$.

restored except for a minimal suppression of the anti- $\mu$ stimulated proliferative response. The second patient in Table IV, studied 10 mo following completion of CY therapy, has normal functions except for a marked suppression of SAC-stimulated PFC responses. All patients studied more than a year after successful completion of the CY therapy had full recovery of $\mathrm{B}$ cell function. The studies presented in Table IV indicate that according to the parameters examined, B cell function returned to normal following cessation of CY therapy.

\section{Discussion}

The present study demonstrates the multifaceted suppression of $B$ cell function in patients with immunologically mediated nonneoplastic diseases receiving chronic low doses of $\mathrm{CY}$. There is a selective suppressive effect of CY therapy on discrete stages of the B cell cycle including both proliferation and differentiation. Knowledge of the effects of chronic low-dose CY on the human immune response has been limited (12-16). Data concerning the effects of CY therapy on $\mathrm{T}$ lymphocyte function have been variable. Mitogenic responses to $T$ cell lectins have been reported to be suppressed in patients with rheumatoid arthritis $(14,15)$

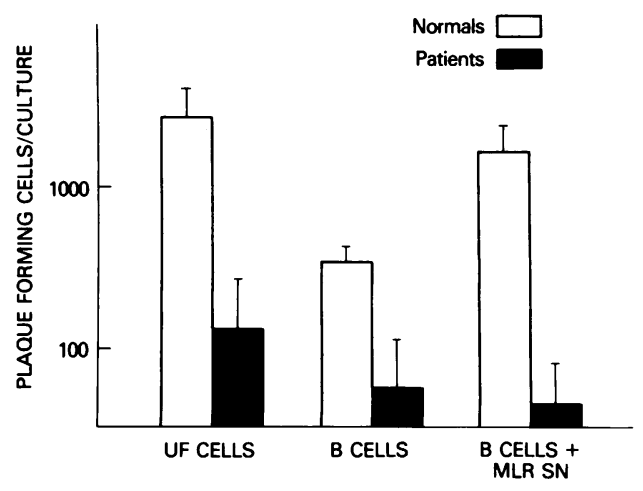

Figure 5. Geometric mean number of PFC per culture ( $\dot{\dot{\times}}$ SEM) in 6 normals and 6 patients being treated with $C Y$. $U F$ represents unfractionated peripheral blood mononuclear cells; $B$ represents T cell-depleted fractions containing B lymphocytes and monocytes; $M L R-S N$ mixed lymphocyte reaction supernatants. The results for unstimulated B cell cultures were for normals $(110 \dot{\dot{X}} 1.25)$ and patients $(41 \dot{\dot{X}} 1.63)$ PFC per culture.

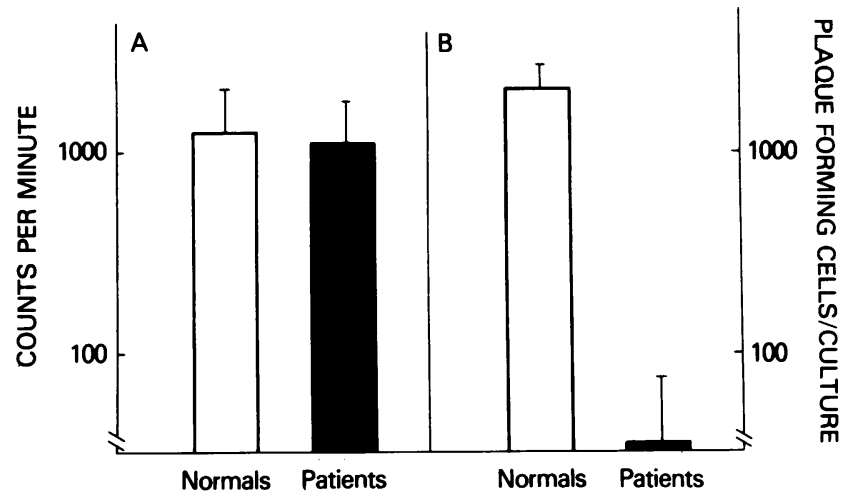

Figure 6. $(A)$ Geometric mean cpm $(\dot{\dot{X}} \mathrm{SEM})$ in four normals and four patients on CY following $3 \mathrm{~d}$ in culture with PWM-SN. (B) Geometric means number of PFC per culture ( $\dot{\dot{X}} \mathrm{SEM})$ in six normals and three patients on CY after $6 \mathrm{~d}$ in culture with $50 \%$ PWM-SN.

but unaltered in patients with vasculitic diseases $(13,15)$ treated with $C Y$. Blastogenic responses to $T$ cell antigens $(13,14)$ and induction of delayed hypersensitivity responses to a new antigen (14) can be suppressed during chronic therapy with CY. In contrast, impairment of concanavalin A-inducible suppressor activity and potentiation of delayed-type hypersensitivity responses to a new antigen have been reported $(32,33)$ several days after a single dose of CY. Active metabolites of CY augment human natural killer cell activity in vitro (34). The $T$ helper cell function such as the ability to provide "help" in T cell-dependent PWMstimulated Ig production is unaltered by chronic CY therapy (16). Although Ig production may be augmented shortly after initiation of CY therapy (33), B cell function is suppressed by chronic low-dose CY therapy. Both reduction of serum Ig levels $(12,14)$ and suppression of in vitro Ig production following PWM stimulation (16) have been reported. Exposure to CY metabolites that are active in vitro also suppresses $B$ cell function (35). In this report, we have evaluated the effects of $C Y$ therapy on the different phases of the B cell cycle from proliferation to differentiation. In patients treated with chronic low doses of CY, the response to the B cell mitogens SAC or high concentrations of anti- $\mu$ is decreased. There are several potential explanations for the suppressed responses. Although the total number of lymphocytes is decreased in patients receiving $\mathrm{CY}$, the percent of

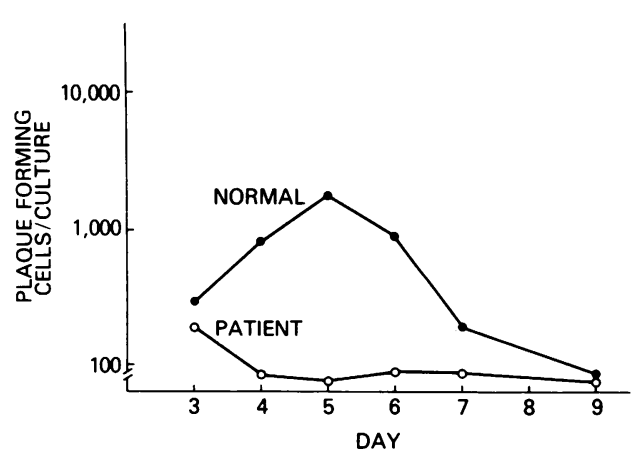

Figure 7. Arithmetic mean number of PFC per culture of four replicate culture points from a patient being treated with CY (open circles) and a normal (solid circles) following different numbers of days in culture. 
Table IV. Recovery of B Cell Function Following Completion of CY Therapy

\begin{tabular}{|c|c|c|c|c|}
\hline & \multicolumn{2}{|l|}{ Proliferation* } & \multicolumn{2}{|c|}{ Differentiation (PFC/culture) ${ }^{*}$} \\
\hline & SAC & Anti- $\mu$ & SAC & PWM-SN \\
\hline & $c p m$ & $c p m$ & & \\
\hline Patients on $\mathrm{CY}^{\S}$ & $802 \dot{\bar{x}} 1.33^{\S}$ & $535 \dot{\dot{x}} 1.279^{8}$ & $34.1 \dot{\dot{\grave{X}}} 2.1^{11}$ & $14.9 \dot{\dot{\dot{x}}} 2.6^{9}$ \\
\hline Patient off CY $1.5 \mathrm{mo}^{* *}$ & 4,065 & 1,391 & 2,000 & 2,540 \\
\hline Patient off CY $10 \mathrm{mo}^{* *}$ & 3,487 & 2,242 & 155 & 2,390 \\
\hline Patient off CY $17 \mathrm{mo}^{* *}$ & 14,879 & 6,788 & 18,000 & 4,040 \\
\hline Patient off CY $18 \mathrm{mo}^{* *}$ & 14,049 & 1,785 & 3,160 & 1,040 \\
\hline Patient off CY $34 \mathrm{mo}^{* *}$ & 6,864 & - & 19,200 & - \\
\hline Patient off CY $54 \mathrm{mo}^{* *}$ & 14,049 & 1,785 & 2,300 & 7,340 \\
\hline Patient off CY $132 \mathrm{mo}^{* *}$ & 10,287 & 13,462 & 4,190 & - \\
\hline 8 normals & $3,953 \dot{\dot{x}} 46^{8}$ & $1,845 \dot{\dot{x}} 1.49^{8}$ & $1,813 \div \dot{\dot{x}} 1.56$ & $2,404 \dot{\dot{x}} 1.35^{1}$ \\
\hline
\end{tabular}

* Proliferative responses to SAC and anti- $\mu$ (goat $\mathrm{F}\left[\mathrm{ab}^{\prime}\right]_{2}$ antihuman IgM) expressed in cpm. ${ }^{\ddagger}$ Differentiation is expressed as PFC per culture in SAC and PWM-SN systems. "See Table III. "See Fig. 5. 'See Fig. 6 B. ** Mean $(\dot{\dot{X}}$ SEM) cpm of triplicate points in proliferative responses and duplicate points in PFC responses from single experiments.

$\mathrm{sIg}^{+}$cells in the UF peripheral mononuclear cell fractions as well as the TCD fractions was similar in the treated and control groups. Moreover, the patterns of the sIg isotypes were similar for the two groups suggesting that the decreased mitogenic responses were not the result of a decrease in the total number of B cells in culture or an alteration in the profile of the B cell subsets. Neither viability in culture nor suppression by accessory cells such as monocytes could explain the decreased proliferative responses to $B$ cell mitogens.

Because of the suppression of B cell proliferation, earlier events in the B cell cycle were evaluated in patients receiving CY. After in vitro stimulation of normal B cells by SAC or anti- $\mu$, the cells undergo enlargement and express the phenotypic markers of activation, $4 \mathrm{~F}_{2}$ and $5 \mathrm{E}_{9}$ (31). These events occur within the first $36 \mathrm{~h}$ after stimulation and correlate with the cells entering in $G_{1}$ phase of the cell cycle and thus precede the $S$ or DNA synthesis phase when tritiated thymidine is incorporated into the cellular DNA. In this report we demonstrate that there are increased numbers of enlarged B cells in the peripheral blood of patients being treated with chronic low doses of CY. Furthermore, these cells do not enlarge when stimulated with anti- $\mu$ in vitro. Despite the increased B cell size, there is no increased expression of either phenotypic marker of activation, $4 \mathrm{~F}_{2}$ or $5 \mathrm{E}_{9}$, that are characteristically seen following in vitro activation. Furthermore, $B$ cell proliferative responses to BCGF are qualitatively and quantitatively similar in the CY-treated and normal groups. Thus, despite the presence of enlarged $B$ cells in the blood of CY-treated patients, the absence of the phenotypic markers of activation and a normal response to BCGF suggest that these cells are not in an altered state of activation in vivo. In this regard, enlargement of other cell populations, including T lymphocytes (36) and erythrocytes (T. R. Cupps and A. S. Fauci, unpublished observation) has been noted during treatment with CY. The B cell enlargement appears to be part of the megaloblastic changes characteristically seen during therapy with alkylating agents (37).

In vitro Ig production is also suppressed by CY therapy. The Ig production in B cell preparations stimulated with SAC in the presence of a T cell-derived differentiation signal (MLR-SN) is suppressed. As previously noted, the earlier events of SAC-stimulated activation and proliferation are also substantially suppressed. Consequently, the low levels of Ig production could be related to either suppressed activation/proliferation, altered differentiation, or a combination of the two activities. To delineate the potential relationship between the defective proliferation and suppressed differentiation of B cells, a second culture system was employed. When normal peripheral blood B cells are separated into small resting cells and large, in vivo-activated cells, the B cells that proliferate and produce Ig in response to PWM$\mathrm{SN}$ are found in the latter group. This observation suggests that the soluble factors found in the PWM-SN are sufficient to cause proliferation and differentiation in normal large peripheral blood B cells activated in vivo. The B cells from patients treated with CY in fact do proliferate in response to PWM-SN or monoclonal BCGF when compared with normal B cells suggesting that a subset of B cells from patients receiving CY have been activated in vivo to the point where the cells can proliferate to the appropriate soluble factors. Despite the presence of these BCGF-responsive B cells in the peripheral blood, PWM-SN-stimulated Ig production is suppressed in patients receiving CY. This observation suggests that CY therapy suppresses the differentiation of B lymphocytes to Ig-producing cells, including B cells stimulated to a BCGF-responsive state in vivo. Thus, in addition to the suppression of the activation/proliferation sequence, chronic low-dose CY therapy suppresses the differentiation phase of the $B$ cell maturation sequence.

The precise mechanisms by which CY therapy suppresses the activation/proliferation process of $B$ cells in response to the initial in vitro activation signals is unclear. Conceivably, chronic CY therapy could affect one or several of the multiple steps in the B cell activation/proliferation sequence between the delivery of the activation signal at the $B$ cell membrane to the expression of B cell proliferation. Because the proliferative response to these activation signals depends on the integrity of the activation process, it is unclear at present whether the subsequent proliferative responses to these signals are directly suppressed by CY therapy 
or the suppressed proliferation is merely a consequence of the suppression of the initial activation signal. Clearly, a subset of peripheral blood B cells from patients receiving CY proliferate in the presence of BCGF in the absence of any additional in vitro activation signals in a pattern comparable to normal $B$ cells. Thus, suppression of the B cell proliferative process itself is not an invariable result of CY therapy.

Following completion of CY therapy the peripheral blood $B$ cell functional parameters of the patients returned to normal. The rate of recovery may be variable from individual to individual. One patient had normal peripheral B cell function $6 \mathrm{wk}$ after the last dose of CY. In another patient, one of the two parameters of differentiation was still suppressed 10 mo after completion of therapy. However all B cell functional parameters, including proliferation and differentiation, were normalized within $1 \mathrm{yr}$ of completion of the CY therapy. Relatively little information is available on the long-term effects of chronic lowdose CY on leukocyte function. Longterm suppression of bone marrow-derived granulocyte colony formation was noted in patients with rheumatoid arthritis remotely treated with CY (38). The long-term suppression of granulocyte colony formation suggests that $C Y$ therapy may have persisting effects on the hematopoietic system. Despite this observation, full recovery of peripheral $\mathrm{B}$ cell proliferation and differentiation responses is characteristic following completion of chronic low-dose CY therapy.

These observations provide new insights into the mechanisms of chronic low-dose CY-mediated immunosuppression and should provide an additional scientific basis for the rational uses of this potent and effective immunosuppressive agent.

\section{Acknowledgments}

The authors wish to thank Susan O. Sharrow for performing the FACS studies. The authors also gratefully acknowledge the expert editorial assistance of Ms. Carol Moran and Ms. Ann London.

\section{References}

1. Fauci, A. S., B. F. Haynes, and P. Katz. 1978. The spectrum of vasculitis. Clinical, pathologic, immunologic, and therapeutic considerations. Ann. Intern. Med. 89:660-676.

2. Gershwin, M. E., J. Goetzel, and A. D. Steinberg. 1974. Cyclophosphamide: use of clinical practice. Ann. Intern. Med. 80:531-540.

3. Cupps, T. R., and A. S. Fauci. 1981. The vasculitides. Major Probl. Intern. Med. 21:1-211.

4. Fauci, A. S., B. F. Haynes, P. Katz, and S. M. Wolff. 1983. Wegener's granulomatosis: prospective clinical and therapeutic experience with 85 patients for 21 years. Ann. Intern. Med. 98:76-85.

5. Fauci, A. S., P. Katz, B. F. Haynes, and S. M. Wolff. 1979. Cyclophosphamide therapy of severe systemic necrotizing vasculitis. $N$. Engl. J. Med. 301:235-238.

6. Fauci, A. S., B. F. Haynes, J. Costa, P. Katz, and S. M. Wolff. 1982. Lymphomatoid granulomatosis. Prospective clinical and therapeutic experience over 10 years. N. Engl. J. Med. 306:68-74.

7. Salvin, J. B., and R. F. Smith. 1964. The specificity of allergic reaction. VII. Immunologic unresponsiveness, delayed hypersensitivity, and circulating antibody to proteins and hapten-protein conjugates in adult guinea pigs. J. Exp. Med. 119:851-868.

8. Rollinghoff, M., A. Starzinski-Powitz, K. Pfizenmaier, and H. Wagner. 1977. Cyclophosphamide-sensitive T lymphocytes suppress the in vitro generation of antigen-specific cytotoxic T lymphocytes. J. Exp. Med. 145:455-459.
9. Howard, J. G., and F. L. Shand. 1979. The nature of drug-induced B cell tolerance. Immunol. Rev. 43:43-68.

10. Hurme, M. 1979. Differential cyclophosphamide sensitivity of precursor cells in allogeneic and $\mathrm{H}-2$ restricted cytotoxic responses. $J$. Exp. Med. 149:290-294.

11. Diamanstein, T., E. Willinger, and J. Reiman. 1979. T-suppressor cells sensitive to cyclophosphamide and to its in vitro active derivative 4-hydroxycyclophosphamide control the mitogen response of murine splenic B cells to dextran sulfate. J. Exp. Med. 150:1571-1576.

12. Fauci, A. S., S. M. Wolff, and J. S. Johnson. 1971. Effect of cyclophosphamide upon the immune response in Wegener's granulomatosis. N. Engl. J. Med. 285:1493-1496.

13. Fauci, A. S., D. C. Dale, and S. M. Wolff. 1974. Cyclophosphamide and lymphocyte subpopulations in Wegener's granulomatosis. $A r$ thritis Rheum. 17:355-361.

14. Alepa, F. P., N. J. Zvaiffler, and A. J. Sliwinski. 1979. Immunologic effects of cyclophosphamide treatment in rheumatoid arthritis. Arthritis Rheum. 13:754-760.

15. Winkelstein, A., J. M. Mikulla, H. R. Nankin, B. H. Pollock, and B. L. Stolzer. 1972. Mechanisms of immunosuppression: effects of cyclophosphamide on lymphocytes. J. Lab. Clin. Med. 80:506-513.

16. Cupps, T. R., L. C. Edgar, and A. S. Fauci. 1982. Suppression of human B lymphocyte function by cyclophosphamide. J. Immunol. 128:2453-2457.

17. Kishimoto, T., T. Miyake, Y. Nishizawa, T. Watanabe, and Y. Yamamura. 1975. Triggering mechanisms of B lymphocytes. I. Effect of anti-immunoglobulin and enhancing soluble factor on differentiation and proliferation of B cells. J. Immunol. 115:1179-1184.

18. Falkoff, R. J. M., L. P. Zhu, and A. S. Fauci. 1982. Separate signals for human B cell proliferation and differentiation in response to Staphylococcus aureus. Evidence for a two-signal model for B cell activaton. J. Immunol. 129:97-102.

19. Muraguchi, A., T. Kasahara, J. J. Oppenheim, and A. S. Fauci. 1982. B cell growth factor and T cell growth factor produced by mitogenstimulated normal human peripheral blood $\mathrm{T}$ cells are distinct molecules. J. Immunol. 129:2486-2489.

20. Butler, J. L., A. Muraguchi, H. C. Lane, and A. S. Fauci. 1983. Development of a human T-T cell hybridoma secreting B cell growth factor. J. Exp. Med. 157:60-68.

21. Muraguchi, A., J. L. Butler, J. H. Kehrl, and A. S. Fauci. 1983. Differential sensitivity of human B cell subsets to activation signals delivered by anti- $\mu$-antibody and proliferative signals delivered by a monoclonal B cell growth factor. J. Exp. Med. 157:530-546.

22. Falkoff, R. M., M. Peters, and A. S. Fauci. 1982. T cell enrichment and depletion of human peripheral blood mononuclear cell preparations. Unexpected findings in the study of the functional activities of the separated populations. J. Immunol. Methods. 50:39-49.

23. Gerrard, T. L., and A. S. Fauci. 1982. Activation and immunoregulation of antigen-specific human B lymphocyte responses. Multifaceted role of the monocyte. J. Immunol. 128:2367-2372.

24. Thiele, D. L., M. Kurosaka, and P. E. Lipsky. 1983. Phenotype of the accessory cell necessary for mitogen-stimulated $T$ and $B$ cell responses in human peripheral blood: delineating by sensitivity to the lysosomotropic agent L-leucine methyl ester. J. Immunol. 131:2282-2290.

25. Sjoberg, O., and J. Kurnick. 1980. Conditions for induction of specific and polyclonal antibody production by Cowan I bacteria and by pokeweed mitogen. Scand. J. Immunol. 11:47-51.

26. Eisenbarth, G. S., B. F. Haynes, J. A. Shroer, and A. S. Fauci. 1980. Production of monoclonal antibodies reacting with peripheral blood mononuclear cell surface differentiation antigens. J. Immunol. 124:12371244.

27. Haynes, B. F., M. E. Hemler, D. L. Mann, G. S. Eisenbarth, J. Shelhamer, H. S. Mostowski, C. A. Thomas, J. L. Strominger, and A. S. Fauci. 1981. Characterization of a monoclonal antibody (4F2) that binds to human monocytes and to a subset of activated lymphocytes. $J$. Immunol. 126:1409-1414. 
28. Haynes, B. F., M. Hemler, T. Cotner, D. L. Mann, G. S. Eisenbarth, J. L. Strominger, and A. S. Fauci. 1981. Characterization of a monoclonal antibody (5E9) that defines a human cell surface antigen on cell activation. J. Immunol. 127:347-351.

29. Fauci, A. S., G. Whalen, and C. Burch. 1980. Activation of human B lymphocytes. XVI. Cellular requirements, interactions, and immunoregulation of pokeweed mitogen-induced total-immunoglobulin-producing plaque-forming cells in peripheral blood. Cell. Immunol. 54:230240.

30. Hirano, T., T. Kuritani, T. Tadamitsu, and Y. Yamamura. 1977. In vitro immune response of human peripheral lymphocytes. 1 . The mechanism(s) involved in $\mathrm{T}$ cell helper functions in the pokeweed mitogen-induced differentiation and proliferation of B cells. J. Immunol. 119:1235-1241.

31. Kehrl, J. H., A. Muraguchi, and A. S. Fauci. 1984. Differential expression of cell activation markers after stimulation of resting human B lymphocytes. J. Immunol. 132:2857-2861.

32. Berd, D., H. C. Maguire, Jr., and M. J. Mastranglo. 1981. Impairment of Concanavalin A-inducible suppressor activity following administration of cyclophosphamide to patients with advanced cancer. Cancer Res. 44:1275-1280.
33. Berd, D., H. C. Maguire, Jr., and M. J. Mastranglo. 1984. Potentiation of human cell-mediated and humoral immunity by low-dose cyclophosphamide. Cancer Res. 44:5439-5443.

34. Sharma, B., and N. D. Vaziri. 1984. Augmentation of human natural killer cell activity by cyclophosphamide in vitro. Cancer Res. 44: 3258-3261.

35. Ozer, H., J. W. Cowens, M. Colvin, A. Nussbaum-Blumenson, and D. Sheedy. 1982. In vitro effects of 4-hydroperoxycyclophosphamide on human immunoregulatory T subset function. J. Exp. Med. 155:276290.

36. Clements, P., J. Levy, and E. V. Barnett. 1973. Immunosuppressive effects on B-lymphocytes in rheumatoid arthritis. Arthritis Rheum. 16:537-538.

37. Calabresi, P., and R. E. Parks. 1975. Alkylating agents, antimetabolites, hormones, and other antiproliferative agents. In The Pharmacological Basis of Therapeutics. L. S. Goodman and A. G. Gilman, editors. Macmillan Publishing Co., Inc., New York. Fifth ed. 1254-1268.

38. Thomas, M. R., W. A. Robinson, D. J. Bogle, J. F. Day, M. A. Entringer, and J. F. Streigerwald. 1983. Longterm effects of cyclophosphamide on granulocytic colony formation in patients with rheumatoid arthritis. J. Rheumatol. 10:778-783. 